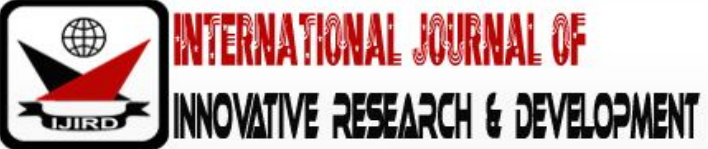

ISSN 2278 - 0211 (Online)

\section{Assessment of Youth Unemployment, Security and Corruption in Nigeria: 1986-2015}

G. Udi
Principal Lecturer, Department of Business Administration, Delta State Polytechnic, Nigeria
Dr. B.O. Ohwofasa
Lecturer, Department of Social Sciences (Economics Unit), Delta State Polytechnic, Nigeria
J. Erakpoweri
Lecturer, Department of Social Sciences (Citizenship Unit), Delta State Polytechnic, Nigeria

\begin{abstract}
:
The paper examines impact of insecurity and corruption on unemployment in Nigeria. Unemployment has been on the increase and government's effort aimed at addressing the problem has been ineffective. This situation is compounded by the fact that high level of corruption prevented the provision of soft and hard infrastructures that would have mitigated against unemployment. An empirical assessment of this issue is scarce as existing literatures mainly focus on the relationship between economic growth and corruption as well as insecurity. The study employed both descriptive and econometric methods to analyze the data. The data obtained from various issues of the Central Bank of Nigeria statistical bulletins and annual reports as well as Transparency International covered the period 1986-2015. Consequently, the model was estimated using cointegration and error correction method. The study found that unemployment has a long-run relationship with corruption and government expenditure on defence. Thus, in the long run, unemployment had a positive and significant response to changes in corruption perception index $(0.72 \%)$ and corruption rank $(0.28 \%)$ contrary to its $2.63 \%$ response to government expenditure on defence. Finding also indicate that a $1 \%$ increase in corruption perception index, corruption rank as well as a dummy of insecurity led to increase in unemployment by about $0.26 \%, 0.98 \%$ and $0.27 \%$ respectively in the short run. Therefore, government may consider improvement in security and eradication of corruption in order to mitigate unemployment. Consequently, the fight against corruption should involves appointment of those with integrity to head the anti-graft agencies.
\end{abstract}

Keyword: Unemployment, security, military expenditure, corruption and Error Correction Model (ECM)

\section{Introduction}

Corruption is Nigeria's biggest challenge. It is found in every sector of the society either small or big sector and there is every possibility of observing corrupt practices when critically examined. Nigeria, the most populated country in Africa, has been ranked high in corruption by Transparency International (TI) and other notable organizations that monitor corrupt practices around the world. The country featured for the first time in the Corruption Perception Index (CPI) of TI in 1996 and has continuously been ranked as among the world most corrupt countries. In 2001 for example, Nigeria was ranked 90 out of 91 countries surveyed by TI. Ten years later the country was ranked 143 out of 182 countries in 2011 and has consistently maintained 136 positions out of 175 countries between 2012 and 2015. Corruption in Nigeria wears many kinds of unattractive and dirty clothes. For instance, it takes many shapes ranging from embezzlement, bribery, rituals to rigging in elections and so on. In both the Senate and the House of Representatives as well as State Houses of Assembling corruption is seen as normal. A recent case of corruption in Nigeria is the $\$ 2.1$ billion arms deal. The money which was budgeted for the purchase of arms in the fight against Boko Haram insurgency suddenly disappeared. The situation has made so many people feel a lot of pains as the money which could have been used to provide jobs and reduce unemployment are siphoned by small group of persons.

Another sufficient episode that affects economic indicators such as unemployment in Nigeria is insecurity which is a manifestation of deep-rooted and structurally entrenched crisis of development that creates the environment for the emergence of poverty, unemployment and inequality. These lead to frustration, alienation and social discontent that spark violence and insecurity. Without the enabling environment, these conditions could not have metamorphosed into serious national security problems threatening to tear the country apart. The Boko Haram insurgency has not only claimed thousands of lives, it has also seen daring terrorists hang their flag in parts of the country, especially in the northeast states of Adamawa, Borno and Yobe. At the eve of President Jonathan Administration in 2015, it was reported by the Nigeria media that the terrorist sects have annexed territories for themselves which was almost the size of Belgium. A report of the Internal Displaced Monitoring Centre and the Norwegian Refugee Council indicates that of 33 million internal refugees 
across the world, about 3.3 million Nigerians are internally displaced due to the Boko Haram insurgency (Pointblanknews.com). The number of dislodged victims of the six-year-old by the terrorists in the affected areas is not only thought-provoking but also a cause for concern because it suggests that the scale of the problem may not have been fully captured and may indeed be beyond the range of the available figures. Evidently, the Boko Haram wars has left about 20,000 people dead and forced over 2.6 million people to flee their homes and were camped as IDPs (The Vanguard, 2015). The activities of the sects affected agriculture and other economic activities in the north most especially the north east.

The insecurity problem is also most prevalence in the south-south and south east where armed robbery and kidnapping are regarded as normal. The Niger Delta Avengers (NDA) that is blowing up oil and gas pipelines complicates the security problems. Apart from costing the federal government millions of dollars on dialing basis, a lot of jobs have been lost as most oil companies have shut down production. To appreciate how insecurity contributes to unemployment in Nigeria is to cite a recent case of an industrialist who entered into agreement with a Romanian firm to set up an agro-allied industry in Nigeria which will in its first year employ 1,000 workers. Consequently, the investors came to Nigeria to formalize the agreement and process other requirements for the take-off of the project. The hotel where they lodged was on generator 24 hours daily which raised their suspicion over the state of power supply in the country. The second day of their visit, they were robbed on their way back to the hotel. The following morning, they left for the airport and departed for their country without parting words to their Nigerian business partner thereby ending the business transaction. This shows how bad the economy is in its inability to reduce unemployment.

Thus, corruption and insecurity have contributed to youth unemployment in Nigeria which is increasing with leaps and buds. The magnitude of the unemployment in the country will be better appreciated by making reference to the statement of the former Chairman of the Subsidy Re-investment Programme (SURE-P), Christopher Kolade. He noted that 40 million Nigerians or $23.9 \%$ of the population are unemployed as a result of the inability of the system to absorb the approximately 300,000 graduates churned out of tertiary institutions annually. This figure may not necessarily include the chronically underemployed such as casual workers, or those who are employed seasonally. Unemployment in Nigeria is mounting daily. For instance, the manufacturing sector which used to be the major employer of labour is already comatose as many have closed shop in Nigeria and relocated to neighbouring West African countries or South Africa that provide enabling environment for business to thrive. The banks are downsizing at a ridiculous rate while access to loan has become an official publicity stunt. More devastating is the fact that the government has failed to provide stable power supply and security that are central to industrialization and by extension employment generation and general development of the country. Thus, with corruption and insecurity in Nigeria, unemployment will continue to mount thereby constituting impediment to national development. It is against this backdrop that the current study is germane.

The objective of the study therefore is to assess the impact of corruption and insecurity on unemployment in Nigeria. The rest of the paper is structured as follows. Section two presents review of related literature. In section three, the model is highlighted. Whilst section four presents and discusses the results, section five concludes the paper with policy implications.

\section{Review of Related Literature}

The population of every economy is divided into two categories, the economically active and the economically inactive. The economically active population (labor force) or working population refers to the population that is willing and able to work, including those actively engaged in the production of goods and services (employed) and those who are unemployed (Njoku and Okezie, 2011). The next category, the economically inactive population refers to people who are neither working nor looking for jobs. World Bank (2008) defines the unemployed as numbers of the economically active population who are without work but available for and seeking for work, including people who have lost their jobs and those who have voluntarily left work. Examples include housewives, full time students, those below the legal age for work, old and retired persons. However, the application of this definition across countries has been faulted, especially for the purpose of comparison and policy formulation as countries characteristics are not the same in their commitment to resolving unemployment problems (Akintoye, 2008). Thus, unemployment can be defined as those people who are willing and are capable of work but are unable to find suitable paid employment (Aiyedogbon and Ohwofasa, 2012). In the Nigeria context, unemployment is defined as the proportion of labour force that is available for work but did not work in the week proceeding the survey period for at least 39 hours (NBS, 2012).

The concept of insecurity connotes different meanings such as absence of safety, danger, hazard, uncertainty, protection and so on. It is simply a situation in which individuals in a given society cannot go about their daily activities as a result of threat to and harmful disruption of their lives and property. According to Beland (2005), insecurity entails lack of protection from crime and lack of freedom from psychological harm including freedom from fear. Achumba, Ighomereho and Akpan-Robaro (2013) define insecurity from two perspectives. The first is that insecurity is the state of being open or subject to danger or threat of danger, where danger is the condition of being susceptible to harm or injury. In the second perspective, insecurity is seen as the state of being exposed to risk or anxiety, where anxiety is a vague unpleasant emotion that is experienced in anticipation of some misfortune. These definitions underscore a major point that those affected by insecurity are not only uncertain or unaware of what would happen but they are also vulnerable to the threats and dangers when they occur. On his part, Ewetan and Urhie (2014) defined insecurity as a breach of peace and security, whether historical, religious, ethno-regional, civil, social, economic and political that contributes to recurring conflicts and leads to wanton destruction of lives and properties.

The various crimes in Nigeria such as Boko Haram insurgency, militancy in the Niger Delta, armed robbery and kidnapping as well as agitation by Indigenous People of Biafra (IPOB) constitute insecurity. These crimes are predicated 
on the frustration-aggression theory developed by John Dollard in 1939 and expanded by Leonard Berkowitz (1962) and Yates (1962). This theory states that aggression is not just undertaken as a natural reaction on instinct as realists and biological theorists assume, but that it is the outcome of frustration and that in a situation where the legitimate desires of an individual is derived either directly or by the indirect consequence of the way the society is structured, the feeling of disappointment may lead such a person to express his anger through violence that will be directed on those he holds responsible or people who are directly or indirectly related to them. Thus, the theory is the most common explanation for violent behaviour stemming from inability to fulfill needs.

Corruption, according to Transparency International, is an abuse of entrusted power for private gain. It is an unethical behavior that runs counter to the accepted social norms and moral values which seriously hurts public morality and leaves the society worse for it (Victor, 2003). Thus, corruption refers to abuse of public office for private gains through rent seeking activities when an official accepts, solicits or extorts bribes. Public office can also be abused for personal benefit even if no bribery occurs such as the theft of state assets or the diversion of state resources (Basu, Bhattacharya and Mishra, 1992). Notably, corruption is giving, offering or receiving gratification or bribe or some other form of illegal benefit. In Nigeria these include, but not limited to, trading Chieftaincy titles for financial or material gains, examination scores for money, sexual gratification or other benefits. Refusal to do one's job unless and until the person receives an inducement for himself or on behalf of any other person (Igbaekemen, Abbah and Geidam, 2014).

From the empirical corridor, a couple of recent studies have attempted to examine the contributions of informal sector to employment generation. Ajibefun and Daramola (2003) using a sample of 180 small entrepreneurs examine the efficiency of micro enterprises in the Nigerian economy. The study reported evidence of a wide variation in technical and allocative efficiencies within and across industries. Specifically, the study found that education of owner of business enterprise was a significant factor influencing efficiency thereby increasing employment and reducing unemployment among the firms in the sample. Sanda (2006) uses a sample of 360 firms in Kano and its environs to examine whether or not small firms are relatively better at creation of employment opportunities than large firms. The study found that small firms were relatively better than large firms in employment generation. Muhammad, Oye and Inuwa (2011) examine the relationship between unemployment and gross domestic product (GDP) in Nigeria for the period, 2000-2008. Using regression analysis, findings showed that a $1 \%$ increase in unemployment led to about $65 \%$ decreases in GDP and vice versa. Aiyedogbon and Ohwofasa (2012) examine the relationship between unemployment and incidence of poverty in Nigeria from 1987-2011. Employing OLS they found among other things that poverty had positive and significant response to unemployment $(0.02 \%)$ within the reviewed period.

On the impact of corruption on the economy, studies by Obayelu (2007), Aliyu and Akanni (2008) and Igwike, Hussain and Noman, (2012) as well as Nageri, Gunu and Abdul (2013) found negative relationship between levels of corruption and economic growth in Nigeria thereby making it difficult for the country to develop fast. Nwankwo (2013) employing historical data supported by empirical evidence found that official corruption has negatively affected the operations of poverty reduction efforts in Nigeria. In a study by Action Aid International (2015), it was found that Nigeria scores high in the CPI and scores low in HDI implying that because the incidence of corruption is high, investment in citizens' welfare is low leading to high level of poverty. The study also found that poverty levels in some states where State Governors were found to be guilty of misusing and converting public funds into private use is higher than in states where governors were judicious in the use of public funds. This suggests that if stolen resources were deployed to address the various poverty challenges in these states, the poverty rates should have declined below their present levels. Nwankwo (2014) scrutinizes the impact of corruption on the growth of Nigerian economy using granger causality and regression techniques. The study finds that corruption exerts negative impact on economic growth in Nigeria. Sunkanmi and Isola (2014) investigate the relationship between corruption and economic growth in Nigeria for the period, 1990-2010. Using co-integration and causality tests as well as OLS method, they found a unidirectional causality running from corruption to economic growth. Also, they found that there is no significant relationship between corruption and economic growth in Nigeria. Shuaib, Ekeria and Ogedengbe (2016) examine the impact of corruption on the growth of Nigerian economy using time series data from 1960 to 2012. Employing ECM, the paper found that corruption has an inverse relationship with economic growth in Nigeria. Njiforti, Aiyedogbon and Ohwofasa (2016) assess the relationship between corruption and poverty as well as impact of corruption on economic growth in Nigeria for the period, 1996-2015. The study which employed OLS found that poverty is positively and significantly responsive to corruption while corruption perception index and corruption rank exerted negative impact on economic growth. Studies were also conducted on the impact of insecurity on the economy. Thus, Umaru, Hamza and Haruna (2015) examine impact of insecurity and poverty on sustainable economic development in Nigeria for the period 1981-2013. The study which focuses on Boko Haram insurgency in the north east as an example of insecurity employed OLS technique and Granger causality test to explore the contemporaneous dynamics. The study found that economic growth had negative and significant response to insecurity $(2.82 \%)$ and poverty (3.35\%). The study also found that causality runs from economic growth to poverty as well as from poverty to insecurity in Nigeria.

\section{The Model}

The study utilizes OLS and error correction method. Consequently, the model is specified thus;

$U N M=f(C P I, C R K, G E D)$

In $\log$ stochastic form, equation (1) becomes:

$\operatorname{InUNM}_{t}=\alpha_{0}+\alpha_{1} C P I_{t}+\alpha_{2} C R K_{t}+\alpha_{3} G E D_{t}+\varepsilon$ 
Where: $\mathrm{UNM}=$ unemployment rate, $\mathrm{CPI}=$ corruption perception index, CRK, corruption rank, GED = government expenditure on defence, $\alpha_{0}=$ constant, $\alpha_{1}-\alpha_{3}$ parameters to be estimated, $\mathrm{t}=$ time trend and $\varepsilon=$ error term. A positive relationship is expected to exist between UNM, CPI and CRK while the relationship between UNM and GED is expected to be negative. Increase in defence expenditure adequately utilized should boost security that will increase investment and employment thereby leading to decline in unemployment.

\subsection{Co-Integration Test and Vector Error Correction Model}

Engle and Granger (1987) pointed out that a linear combination of two or more non-stationary series may be stationary. If such stationarity exists, time series are said to be co-integrated. The stationary linear combination is called the co-integrating equation and may be interpreted as a long-run equilibrium relationship between the variables. The cointegrating equation is

$$
\begin{aligned}
& y_{1},_{t}=\beta_{1} y_{2, t}+\varepsilon_{t} \\
& y_{2},_{t}=\beta_{2} y_{1, t}+\varepsilon_{t}
\end{aligned}
$$

and the Vector Error Correction (VEC) form is

$$
\begin{aligned}
& \Delta y_{1, t}=\gamma_{1}\left(y_{2, t-1}-\beta_{1} y_{1, t-1}\right)+v_{1, t} \\
& \Delta y_{2, t}=\gamma_{2}\left(y_{2, t-1}-\beta_{1} y_{1, t-1}\right)+v_{2, t}
\end{aligned}
$$

In equation (4), the only right-hand side variable is the error correction term. In the long run equilibrium, this term is zero. However, if $\mathrm{y}_{1}$ and $\mathrm{y}_{2}$ deviated from long run equilibrium in the last period, the error correction term is non-zero and each variable adjusts to partially restore the equilibrium relationship. The coefficients $Y_{1}$ and $Y_{2}$ measure the speed of adjustment. In the short run, a dummy variable (DUM) capturing insecurity is included in the model.

\section{Data and Discussion}

\subsection{Trend of Unemployment, Corruption and Insecurity in Nigeria}

Successive governments in Nigeria have tried to fight corruption since they realize that it is the root of many woes confronting the country. Since 1999, the country has been under democratic rule and Obasanjo administration in order to tackle corruption headlong established anti-corruption agencies like the Economic and Financial Crime Commission (EFCC) and Independent Corrupt Practices and other related offences Commission (ICPC). Consequently, a number of politicians were investigated and tried. However, there were cries by politicians that the commissions were been used to witch-hurt perceived political enemies.

To observers, the anti-corruption war of the Jonathan administration was not just dead; its remains were interred. The government failed to tackle corruption. The high-profile corruption cases such as the Malabo oil deal, Halliburton contract scam, the $\$ 20$ billion fraud in the NNPC, the N1 trillion debts owed NITEL for the use of its facilities by GSM operators at the inception, the purchase of inflated bullet-proof by former Aviation Minister, Stella Oduah, the dust raised by the Pension Fund scam, Otedola-Farouk saga and other related cases were abiding evidences. One of the perceived weaknesses that cast the Jonathan administration in bad light was the less than forceful presidential presence and ineffective deployment and application of presidential power in calling people around him to order. His actions suggested that he accommodated mediocre elements within his inner circle and that he lacked the will to show them the door. Also, under Jonathan administration the country security situation was seriously compromised in which the Boko Haram insurgency was relatively more pronounced. A good number of local governments from three states of Adamawa, Borno and Yobe were taken over by the terrorists. Many Nigerians were killed and large numbers of people were rendered homeless and sheltered in public schools christened as Internally Displaced People (IDPs). Table 1 showed that since the present democratic experiment, unemployment and corruption have been on the increase with the period of Jonathan administration been relatively more pronounced. However, defence expenditure declined probably due to private diversion as recently revealed by the Dasukegate.

\begin{tabular}{|c|c|c|c|}
\hline Year & Unemployment Rate & Defence Expenditure & Corruption Perception Index \\
\hline $1986-1990$ & 5.28 & 22.44 & - \\
\hline $1991-1995$ & 3.02 & 48.62 & - \\
\hline $1996-2000$ & 8.06 & 49.88 & 1.43 \\
\hline $2001-2005$ & 13.26 & 30.08 & 1.50 \\
\hline $2006-2010$ & 16.20 & 46.30 & 2.42 \\
\hline $2011-2015$ & 25.78 & 16.96 & 21.68 \\
\hline
\end{tabular}

Table 1: Average Growth of Unemployment, Defence Expenditure and Corruption Index (\%)

Source: CBN Annual Report and Statement of Account (Various Issues), TI and Authors' Computation 
Buhari assumed office in May 2015 and he is not new in fighting corruption. In 1983, when he came to power as military Head of State, the corrupt politicians that looted the treasury were brought to book and vomited what they illegally swallowed. In his current short period in office, so many corrupt politicians of the past administration have been quizzed for investigated. Notably, the $\$ 2.1$ billion meant for arms purchase but diverted by politicians to their private pockets referred to as Dasuke gate is most prominent. Although, observers are of the view that only people from opposition party are perceived corrupt while political office holders from the ruling party are clean. The end of the administration will vindicate this view. The administration has made giant strive in terms of security especially in the north east. Boko Haram has been degraded as they no longer hold territories previously acquired. However, security challenge has shifted to the Niger Delta militants that are destroying oil installations with grave economic consequences for Nigeria.

\subsection{Estimation Results}

Table 2 shows that the series were non-stationary at level but at first differencing, stationary was achieved at 5\% level thereby making the variable suitable for Johasen co-integration test.

\begin{tabular}{|c|c|c|c|c|}
\hline Variable & Level & 1st Diff & Order & Included in Test Equation \\
\hline LUNM & -2.74 & -3.65 & $\mathrm{I}(1)$ & Trend \& Intercept \\
\hline LCPI & -1.25 & -3.89 & $\mathrm{I}(1)$ & $"$ \\
\hline LCRK & -1.75 & -4.31 & $\mathrm{I}(1)$ & $"$ \\
\hline LGED & -1.89 & -3.67 & $\mathrm{I}(1)$ & \\
\hline C.V $=5 \%$ & -3.58 & -3.59 & & \\
\hline
\end{tabular}

Table 2: ADF Unit Root Test

Source: Extracted from E-View 8.0

In Table 3, the Johasen and Juselius (1990) co-integration result is presented and it revealed that both the Trace and the Max-Eigen statistics contain at least two co-integrating equations at 1\% significance level.

\begin{tabular}{|c|c|c|c|c|c|}
\hline Null Hypothesis & $\begin{array}{c}\text { Alternative } \\
\text { Hypothesis }\end{array}$ & $\begin{array}{c}\text { Statistical } \\
\text { Value }\end{array}$ & $\mathbf{5 \%}$ C.V & 1\% C.V & Eigen Value \\
\hline \multicolumn{6}{|c|}{ Trace Statistics } \\
\hline $\mathrm{r}=0$ & $\mathrm{r} \geq 0$ & 66.23 & 47.21 & 54.26 & 0.54 \\
\hline $\mathrm{r} \geq 1$ & $\mathrm{r} \geq 1$ & 43.99 & 29.68 & 35.68 & 0.24 \\
\hline $\mathrm{r} \geq 2$ & $\mathrm{r} \geq 2$ & 6.22 & 15.41 & 20.04 & 0.19 \\
\hline $\mathrm{r} \geq 3$ & $\mathrm{r} \geq 3$ & 0.17 & 3.76 & 6.65 & 0.01 \\
\hline \multicolumn{7}{|c|}{ Max-Eigen Statistics } \\
\hline $\mathrm{r}=0$ & $\mathrm{r}=0$ & 42.24 & 27.07 & 32.24 & 0.54 \\
\hline $\mathrm{r} \leq 1$ & $\mathrm{r}=1$ & 27.77 & 20.97 & 25.52 & 0.24 \\
\hline $\mathrm{r} \leq 2$ & $\mathrm{r}=2$ & 6.05 & 14.07 & 18.63 & 0.19 \\
\hline $\mathrm{r} \leq 3$ & $\mathrm{r}=3$ & 0.17 & 3.76 & 6.65 & 0.01 \\
\hline
\end{tabular}

Table 3: Co-Integration Test

Source: Extracted from E-View 8.0

Long Run Regression Results Normalized on UNM

LUNM $=1.00-2.63 \mathrm{LGED}+0.72 \mathrm{LCPI}+0.28 \mathrm{LCRK}$
$(-2.8)$
(4.8)
(5.6)

Log Likelihood $=-254.1$

Thus, there is a long run relationship between unemployment and its determinants. Similarly, it can be found from the lower panel of Table 3 that while government expenditure on defence reduces unemployment, corruption increases it. A unit increase in defence expenditure led to $2.63 \%$ decrease in unemployment while a $1 \%$ increase in CPI and CRK increases unemployment by $0.72 \%$ and $0.28 \%$ respectively in the long run. 


\begin{tabular}{|c|c|c|c|c|}
\hline Variable & Coefficient & Std error & t-statistics & Probability \\
\hline Constant & 0.06 & 0.08 & 0.72 & 0.48 \\
\hline DLUNM(-1) & 0.02 & 0.17 & 0.09 & 0.93 \\
\hline DLGED & 0.17 & 0.15 & 1.12 & 0.27 \\
\hline DLCPI & 0.26 & 0.11 & 2.42 & 0.02 \\
\hline DLCRK & 0.98 & 0.48 & 2.05 & 0.05 \\
\hline DUM & 0.27 & 0.11 & 2.33 & 0.03 \\
\hline ECM(-1) & -0.62 & 0.17 & -3.69 & 0.00 \\
\hline
\end{tabular}

Table 4: Short Run Estimation

Dependent Variable: DLUNM

Method: Least Square

$\mathrm{R}^{2}=0.62 ; \mathrm{DW}=2.04 ; \mathrm{F}$-stat $=3.85$

Source: Extracted from E-View 8.0

Table 4 shows that all the independent variables exert positive relationship on unemployment in the short run. CPI, CRK and a dummy of insecurity are statistically significant meaning that changes in these variables affect unemployment. A $1 \%$ increase in CPI, CRK and DUM increases UNM by $0.26 \%, 0.98 \%$ and $0.27 \%$ respectively. On the other hand, expenditure on defence is statistically insignificant. The ECM observes the usual negative sign and is statistically significant which is what is expected if there is co-integration between the variables. Its coefficient of 0.62 represents $62 \%$ speed of adjustment between the short and the long run due to disequilibrium. The model also shows that the independent variables explained about $62 \%$ of variation in UNM while the F-stat reveals that the model is statistically significant. The DW statistics shows absence of auto-correlation.

The high rate of corruption and insecurity in Nigeria has negative effect on the country development effort. For instance, public funds that are supposed to be used to provide critical infrastructures such as roads, power supply, education and healthcares are diverted to few private pockets. This leads to decline in investment thereby leading to increase in unemployment. Similarly, the seven years Boko Haram insurgency in the north east, the Niger Delta militants, armed robbery and kidnapping across the country, all of which affect investment climate as investors are risk averse.

\section{Conclusion and Recommendation}

The study focuses on the impact of insecurity and corruption on unemployment in Nigeria. In Nigeria, unemployment has been on the increase and government is making little or no effort to address the problem. Every year, thousand of graduates are turned out from higher institutions of learning without any commensurate employment thereby making the youth to roam about the streets. This state of frustration leads to a number of crimes been committed ranging from armed robbery, kidnapping and militancy to insurgency. This problem is compounded by the fact that high level corruption in Nigeria prevented the provision of soft and hard infrastructures that would have mitigated against insecurity problem. The result is high unemployment and poverty which give birth to hunger, anger and danger which is unacceptable for Nigeria development drive.

Against the backdrop, we recommend that to provide employment for the terming Nigerian youths, insecurity and corruption must be death with at all costs. For the government to effectively fight corruption, the administration must consider strengthening the criminal justice system in the country and appoint people of integrity to head the anti-graft agencies. The EFCC, ICPC as well as Code of Conduct Bureau (CCB) and its tribunal should be independent of the Presidency in terms of appointments and financing. The focus of the Buhari Presidency should be on prevention, detection and prosecution of corrupt persons which are fundamental to ending corruption. Also, the capability of the military must be strengthen with high caliber weapons that supersede that of the enemies to enable them inflict colossal damage on the enemies.

\section{References}

i. Achumba, I. C., Ighomereho, O. S., \&Akpan-Robaro, M. O. M. (2013). Security challenges in Nigeria and the Implications for business activities and sustainable development. Journal of Economics and Sustainable Development, 4(2): 79-99.

ii. Action Aid International (2015). Corruption and poverty in Nigeria: A report. Action Aid Nigeria.

iii. Aiyedogbon, J.O. \& Ohwofasa, B.O.(2012). Poverty and youth unemployment in Nigeria, 1987International Journal of Business and Social Science, 3(20): 269-279.

iv. Ajibefun, I. \& Daramola, U, (2003). In Douglason, G.U \& Gbosi, E. (eds). The dynamics of productivity and unemployment nexus: Implications for employment generation in Nigeria. 2006 Annual conference of Nigerian Economic Society, Ibadan, Nigeria.

v. Akintoye, I.R. (2008). Reducing unemployment through the informal sector: A case study of Nigeria. European Journal of Economics, Finance and Administrative Sciences, 11: 1450-2275. http:/ / www.eurojournalsn.com.

vi. Aliyu, SU.R. \& Akanni, O.E. (2008). Corruption and economic growth in Nigeria: 1986 - 2007. MPRA paper, 12504. Posted 6 Jan, 2009 and retrieved from: http:/ / mpra.ub.uni.muenchen.de/ 12505/

vii. Basu, K., Bhattacharya, S. \& Mishra, A. (1992). Notes on bribery and the control of corruption. Journal of Public Economics, 48: 349-359.

viii. Beland, D. (2005). The political construction of collective insecurity: From moral panic to blame avoidance and organized responsibility. Centre for European Studies Working Paper. 
ix. Berkwitz, L. (1963). Aggression: A sociological analysis. New York, McGraw-Hill

x. Engle, R. F. \& Granger, C. W. J. (1987). Co-integration and error correction: Representation, estimation and testing. Econometrics, 55: 251-76.

xi. Ewetan, O.O. \& Urhie, E. (2014). Insecurity and socio-economic development in Nigeria. Journal of Sustainable Development Studies, 5(1): 40-63.

xii. Igbaekemen, G.O., Abbah, M.T. \& Geidam, M.M. (2014). The effect of corruption on socio-economic development of Nigeria. Canadian Social Science, 10 (6): 149-157.

xiii. Igwike, R.S.,Hussain, M.E. \& Noman, A. (2012). The impact of corruption on economic development: A panel data analysis. Research Gate. Retrieved 15 December, 2014 from: http:// ww.researchgate.net/ publication/ 228121173

xiv. Johansen, S. \& Juselius, K. (1990). Maximum likelihood estimation and inferences on co- integration with application to the demand for money. Oxford Bulletin of Economics and Statistics,52: 169-210

xv. Muhammad, S. A., Oye, N.D. \& Inuwa, I. (2011). Unemployment in Nigeria: Implication on the Gross Domesti Product (GDP) over the Years. International Journal of Economics Resources, 2(1), 66-71.

xvi. Nageri, K.I., Gunu, U. \& Abdul, F.A. (2013). Corruption and economic development: Evidence from Nigeria. Kuwait Chapter of Arabian Journal of Business and Management Review， 3(2):46-56.

xvii. National Bureau of Staiatics (2014). Statistical Bulletin of National Bureau of Statistics.

xviii. Njiforti, P.P., Aiyedogbon, J.O. \& Ohwofasa, B.O. (2016, June). An assessment of the impact of corruption on economic growth in Nigeria: 1996-2015. Being a paper presented at the First Faculty of Art International Conference with the theme: The Humanities and National Development held at Adekunle Ajesin University, Akungba Akoko, Ondo State from $27-30$.

xix. Njoku, A. \& Okezie, A. I. (2011). Unemployment and Nigerian economic growth,1985-2009. Proceedings of the 2011 International Conference on Teaching, Learning and Change organized by International Association for Teaching and Learning (IATEL).

xx. Nwankwo, R.N. (2013). Official corruption and poverty reduction in Nigeria: A critical assessment, 2003-2010. International Journal of Arts and Sciences, 6(2): 305-329.

xxi. Nwankwo, O. (2014). Impact of corruption on economic growth in Nigeria. Mediterranean Journal of Social Sciences, 5(6): 41-46.

xxii. Obayelu, A.E. (2007, May). Effects of corruption and economic reforms on economic growth and development: Lessons from Nigeria. Being a paper presented at the African Economic Conference.

xxiii. Sanda, A. (2006). In Douglason, G.U \& Gbosi, E. (2006). The dynamics of productivity and unemployment nexus: Implications for employment generation in Nigeria. 2006 Annual conference of Nigerian Economic Society, Ibadan, Nigeria.

xxiv. Shuaib, I.M., Ekeria, O.A. \& Ogedengbe, A.F. (2016). Impact of corruption on the growth of the Nigerian economy, 1960-2012: Error correction mechanism (ECM). Journal of Scientific Research and Reports, 9(5): 1-13.

xxv. Sunkanmi, O.A. \& Isola, A.L. (2014). Corruption and economic growth in Nigeria. Journal of Economicsand Sustainable Development, 5(6): 45-56.

xxvi. Umaru, A., Hamza, A.P. \& Haruna, A.D. (2015). The impact of insecurity and poverty on sustainable economic development in Nigeria. International Journal of Humanities Social Sciences and Education (IJHSSE), 2(2): 32-48.

xxvii. Victor, B. E. I. (2003). Understanding Nigerian government and politics. Lagos: Newsacks publishing.

xxviii. World Bank (2008). African Development Indicators. The World Bank, Washington, D. C.

xxix. Yate, A. (1962). Frustration and conflict. London, Methuen 